\title{
Spectrophotometric Determination of 1-Naphthylamine - Application to Sea and River Waters
}

\author{
Sameer A. Rahim Dawood H. Mohammed \\ Department of Chemistry \\ College of Science \\ Mosul University
}

(Received 30/ 11/2008 ; Accepted 30/3/2009)

\begin{abstract}
The present work includes a detailed investigation of a new spectrophotometric method for the determination of 1-naphthylamine. The method is based on oxidative coupling reaction of the compound with catechol in the presence of potassium chromate as oxidant in acidic medium to form a stable purple-red coloured product which shows maximum absorption at $530 \mathrm{~nm}$. The molar absorptivity is $36851 . \mathrm{mol}^{-1} \cdot \mathrm{cm}^{-1}$. Beer's law is obeyed over the range of $(1-60) \mathrm{ppm}$. The method is applied to the recovery of 1 naphthylamine from sea and river water.
\end{abstract}

Keywords: Spectrophotometry, 1-naphthylamine, oxidative coupling.

\section{القير اللملف لـ ـ 1-فثل المن - الطبيق علماء البحر والنهر}

\section{الملغص}

يتضمن البمثطريقةطيفية جدية لقدير 1- ففثل المين بقاعل الأكسدة والاقتران، بلستخده كرومات

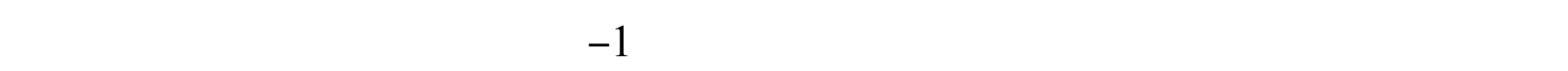

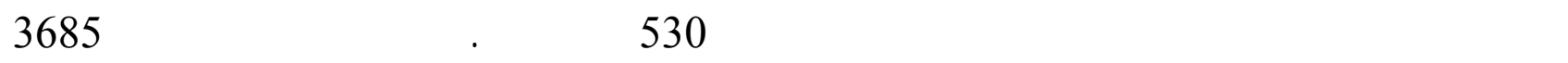

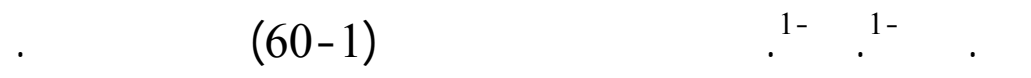

\section{INTRODUCTION}

1-Naphthylamine is used in the preparation of dyes. It is also used for toning photographic prints (Snell,1963). The techniques available for the determination of 1naphthylamine are mainly spectrophotometry. The commonly used methods for the determination of the intended compound can be grouped into three types. Type I methods involving treatment of 1-naphthylamine with nitrite in acidic medium to form a diazonium cation; this is subsequently coupled with an activated aromatic nucleus in either acidic (Norwitz and Keliher,1985) or basic medium (Al-Hemiry,2004), depending on the nature of the coupling component, to form a coloured azo dye for measurement of 1-naphthylamine. Type II methods comprising the coupling of 1-naphthylamine with diazotised reagents to form an intensely-coloured azo dyes. 
In this respect, diazotised sulphanilic acid (Lenkhold,1933), diazotised 3,5dichloroaniline(lug, 1963), diazotized p-aminoacetophenone (Sulaiman and Bashir,1984), diazotised p-nitroaniline (Ismail,1986), diazotized p-aminobenzophenone, and diazotized sulfisomidine (Younis,1994), have been reported for the determination of 1-naphthylamine. Type III methods involving condensation of the determind with a nitroso aromatic compound to form the corresponding coloured azo dye (Koreman,1967 and Jarjees, 2006).

Consequently ,the literature methods revealed that still there is a lack for a more rapid method for determination of 1-naphthylamine. The proposed method is based on oxidative coupling reaction of the compound with catechol in the presence of potassium chromate as oxidant in acidic medium.

\section{Apparatus}

\section{EXPERIMENTAL}

All spectral measurements were performed on Shimadzu UV-visible recording spectrophotometer (UV-160), where as absorbance measurements were carried out on CECIL-CE-1021spectrophotometer. $\mathrm{pH}$ measurements are carried out using a Philips PW $9420 \mathrm{pH}$ meter.

\section{Reagents}

All Chemicals used are of the highest purity available.

Pyrocatechol $\left(2.72 \times 10^{-3} \mathrm{M}\right)$ solution. This solution is prepared by dissolving $0.03 \mathrm{~g}$ of pyrocatechol in distilled water in 100-ml volumetric flask.

Potassium chromate $\left(\mathbf{4 . 6} \times 10^{-3} \mathrm{M}\right)$ solution: $0.09 \mathrm{~g}$ of potassium chromate was dissolved in $100 \mathrm{ml}$ distilled water.

Hydrochloric acid solution: A diluted $(0.05 \mathrm{M})$ was used.

1-Naphthylamine $\left(\mathbf{1 0 0 0 0 ~} \mathbf{~ g ~ m}^{-1}\right) .0 .1 \mathrm{~g}$ is dissolved in ethanol, and the volume is then made up to $10-\mathrm{ml}$ in a volumetric flask. This solution, when stoppered tightly and kept in the refrigerator $\left(\approx 5^{\circ} \mathrm{C}\right)$ is stable for at least 3 months.

Working 1-naphthylamine $50 \mathrm{~g} \mathrm{ml}^{-1}$ solution. a $0.5-\mathrm{ml}$ volume of the stock 1naphthylamine solution is transferred into a $100-\mathrm{ml}$ volumetric flask, and diluted to the mark with distilled water. This solution is stable for at least 1 week.

\section{RECOMMENDED PROCEDURE}

$2.5 \mathrm{ml}$ of pyrocatechol $\left(2.72 \times 10^{-3} \mathrm{M}\right)$ was added into a series of $25-\mathrm{ml}$ calibrated flasks and $2.5 \mathrm{ml}$ of potassium chromate $\left(4.6 \times 10^{-3} \mathrm{M}\right)$ followed by the addition of increasing volumes of $\left(50 \mu \mathrm{g} \mathrm{ml}^{-1}\right)$ 1-naphthylamine solution then $1.5 \mathrm{ml}$ of $(0.05 \mathrm{M})$ hydrochloric acid. The solutions were diluted to the mark with distilled water and the reaction mixture was allowed to stand for 5 minutes. The absorbance of each solution was measured at 530 $\mathrm{nm}$ versus blank prepared in the same manner but without 1-naphthylamine. 


\section{RESULTS AND DISCUSSION}

It was found that the reaction of studied 1-naphthylamine with pyrocatechol in the presence of potassium chromate, a highly coloured purple-red condensation product was obtained with a maximum absorption at $530 \mathrm{~nm}$.

Initial studies were directed towards the optimization of the experimental conditions in order to obtain a good sensitivity, stability and reproducibility of the coloured product.

The influence of various reaction variables on the coloured product was tested to establish the most favourable conditions for the determination of 1-naphthylamine.

\section{Study of the Optimum Reaction Conditions}

The various parameters affecting and related to the above mentioned coloured product have been studied and optimum conditions have been selected.

\section{Effect of reagent concentration}

This effect was studied by placing different volumes of pyrocatechol $\left(2.72 \times 10^{-3} \mathrm{M}\right)$ into a series of $25-\mathrm{ml}$ calibrated flasks, followed by $2.5 \mathrm{ml}$ potassium chromate $\left(4.6 \times 10^{-3} \mathrm{M}\right)$, followed by $5 \mathrm{ml}$ of 1-naphthylamine $\left(50 \mu \mathrm{g} \mathrm{ml}^{-1}\right)$ and $1.5 \mathrm{ml}$ of hydrochloric acid solution $(0.05 \mathrm{M})$. The solutions were diluted to the mark with distilled water. The absorbances were measured at $530 \mathrm{~nm}$ versus blank. The results obtained in Table (1) indicate that the use of $2.5 \mathrm{ml}$ of $\left(2.72 \times 10^{-3} \mathrm{M}\right)$ pyrocatechol reagent gave the maximum colour intensity.

Table 1: Effect of the concentration of reagent on pyrocatechol absorbance

\begin{tabular}{|c|c|c|}
\hline \multirow{2}{*}{$\begin{array}{c}\text { Reagent } \\
\text { conc.(ml) }\end{array}$} & \multicolumn{2}{|c|}{ Absorbance } \\
\cline { 2 - 3 } & A(sample) & A(blank) \\
\hline 1 & 0.197 & 0.065 \\
\hline 2 & 0.237 & 0.078 \\
\hline 2.5 & 0.238 & 0.081 \\
\hline 3 & 0.239 & 0.085 \\
\hline 4 & 0.236 & 0.096 \\
\hline
\end{tabular}

\section{Effect of hydrochloric acid amount}

The effect of the amount of hydrochloric acid was studied by placing into a series of $25-\mathrm{ml}$ calibrated flasks, $2.5 \mathrm{ml}$ of $\left(2.72 \times 10^{-3} \mathrm{M}\right)$ pyrocatechol, $2.5 \mathrm{ml}$ of $\left(4.6 \times 10^{-3} \mathrm{M}\right)$ potassium chromate, followed by $5 \mathrm{ml}$ of $\left(50 \mu \mathrm{g} \mathrm{ml}{ }^{-1}\right)$ 1-naphthylamine and different volumes of $(0.05 \mathrm{M})$ hydrochloric acid. The solutions were diluted to the mark with distilled water. The absorbances were measured at $530 \mathrm{~nm}$ versus blank. The results obtained in Table (2) indicate that the use of $1.0-1.5 \mathrm{ml}$ gave maximum colour intensity, $1.5 \mathrm{ml}$ was selected in all subsequent experiments. 
Table 2: Effect of hydrochloric acid amount on absorbance of the coloured product

\begin{tabular}{|c|c|c|}
\hline $\begin{array}{c}\text { Hydrochloric acid solution } \\
\mathbf{( 0 . 0 5} \mathbf{~ M )}\end{array}$ & Absorbance & Final pH \\
\hline 0.2 & 0.054 & 6.2 \\
\hline 0.4 & 0.158 & 5.43 \\
\hline 0.5 & 0.189 & 4.61 \\
\hline 0.7 & 0.236 & 4.12 \\
\hline 1.0 & 0.239 & 3.39 \\
\hline 1.2 & 0.238 & 3.08 \\
\hline 1.4 & 0.239 & 3.03 \\
\hline 1.5 & 0.240 & 2.84 \\
\hline 1.7 & 0.237 & 2.8 \\
\hline 2 & 0.236 & 2.5 \\
\hline
\end{tabular}

\section{Effect of temperature}

The effect of temperature on the absorbance of the coloured product was studied. This was implemented by placing into three $25-\mathrm{ml}$ calibrated flasks, $2.5 \mathrm{ml}$ of $\left(2.72 \times 10^{-3} \mathrm{M}\right)$ pyrocatechol, $2.5 \mathrm{ml}$ of $\left(4.6 \times 10^{-3} \mathrm{M}\right)$ potassium chromate, followed by $5 \mathrm{ml}$ of $\left(50 \mu \mathrm{g} \mathrm{ml}^{-1}\right)$ 1-naphthylamine, solution and $1.5 \mathrm{ml}$ of $(0.05 \mathrm{M})$ hydrochloric acid solution. The solutions were diluted to the mark with distilled water and the first flask was allowed to stand for increasing time at room temperature, the second was at $0^{\circ} \mathrm{C}$ and the third in water bath at $50^{\circ} \mathrm{C}$. The absorbance was measured at $530 \mathrm{~nm}$ at different periods versus blank prepared in the same way but containing no 1-naphthylamine. The results obtained in Table (3) indicated that the absorbance of the coloured product was decreased when the reaction was carried out at $0^{\circ} \mathrm{C}$ or $50^{\circ} \mathrm{C}$. Therefore, it is recommended that the reaction should be conducted at room temperature

Table 3: Effect of temperature on absorbance of coloured product

\begin{tabular}{|c|c|c|c|}
\hline \multirow{2}{*}{ Time } & \multicolumn{3}{|c|}{ The absorbance } \\
\cline { 2 - 4 } & $0^{\circ} \mathrm{C}$ & R.T $\left(25^{\circ} \mathrm{C}\right)$ & $50^{\circ} \mathrm{C}$ \\
\hline 5 & 0.120 & 0.230 & 0.163 \\
\hline 10 & 0.134 & 0.232 & 0.184 \\
\hline 15 & 0.152 & 0.239 & 0.206 \\
\hline 20 & 0.163 & 0.239 & 0.197 \\
\hline
\end{tabular}




\section{Stability of the product}

This was studied by placing $2.5 \mathrm{ml}$ of $\left(2.72 \times 10^{-3} \mathrm{M}\right)$ pyrocatechol, into a series of 25 $\mathrm{ml}$ calibrated flasks, followed by $2.5 \mathrm{ml}$ of $\left(4.6 \times 10^{-3} \mathrm{M}\right)$ potassium chromate and $5 \mathrm{ml}$ of $(50$ $\left.\mu \mathrm{g} \mathrm{ml} \mathrm{m}^{-1}\right)$ 1-naphthylamine and $1.5 \mathrm{ml}$ of $(0.05 \mathrm{M})$ hydrochloric acid. The solution was diluted to the mark with distilled water and the absorbance was measured at $530 \mathrm{~nm}$ at different periods versus reagent blank. The results obtained in Table (4) show that the product needs 5 minutes to attain maximum absorbance and it remains stable for about 15 minutes.

Table 4: Rate of reaction and stability of product

\begin{tabular}{|c|c|c|c|c|c|c|}
\hline Time (min) & 5 & 10 & 15 & 20 & 25 & 30 \\
\hline Absorbance & 0.239 & 0.238 & 0.239 & 0.237 & 0.229 & 0.217 \\
\hline
\end{tabular}

\section{Order of addition of reagents}

The reagent $2.5 \mathrm{ml}$ of $\left(2.72 \times 10^{-3} \mathrm{M}\right)$ pyrocatechol(R), the oxidant $2.5 \mathrm{ml}$ of $\left(4.6 \times 10^{-3} \mathrm{M}\right)$ $(\mathrm{OX})$ and the sample $5 \mathrm{ml}$ of $\left(50 \mu \mathrm{g} \mathrm{ml}^{-1}\right) 1$-naphthylamine solution, followed by $1.5 \mathrm{ml}$ hydrochloric acid $(0.05 \mathrm{M})$ were mixed in various orders as shown in Table (5).

The results indicate that order (I) gives higher absorbance of the product and therefore it was selected in all subsequent experiments.

Table 5: Effect of order of addition on the absorbance of the coloured product

\begin{tabular}{|c|c|c|}
\hline Reaction components & Order number & Absorbance at $\mathbf{5 3 0} \mathbf{~ n m}$ \\
\hline $\mathrm{R}+\mathrm{OX}+\mathrm{S}+\mathrm{A}$ & $\mathrm{I}$ & 0.238 \\
\hline $\mathrm{R}+\mathrm{S}+\mathrm{OX}+\mathrm{A}$ & $\Pi$ & 0.211 \\
\hline $\mathrm{S}+\mathrm{R}+\mathrm{A}+\mathrm{OX}$ & $\mathrm{U}$ & 0.228 \\
\hline $\mathrm{OX}+\mathrm{S}+\mathrm{R}+\mathrm{A}$ & $\mathrm{IV}$ & 0.180 \\
\hline
\end{tabular}

\section{Final absorption spectra}

Using the optimum conditions described above, the 1-naphthylamine-pyrocatechol complex formed has an absorption spectrum ranging between 475 and $590 \mathrm{~nm}$ with a maximum absorption at $530 \mathrm{~nm}$ in contrast to the reagent blank which shows small absorption at $\lambda$ max. Therefore, the $530 \mathrm{~nm}$ wavelength of maximum absorption has been selected for subsequent work. 


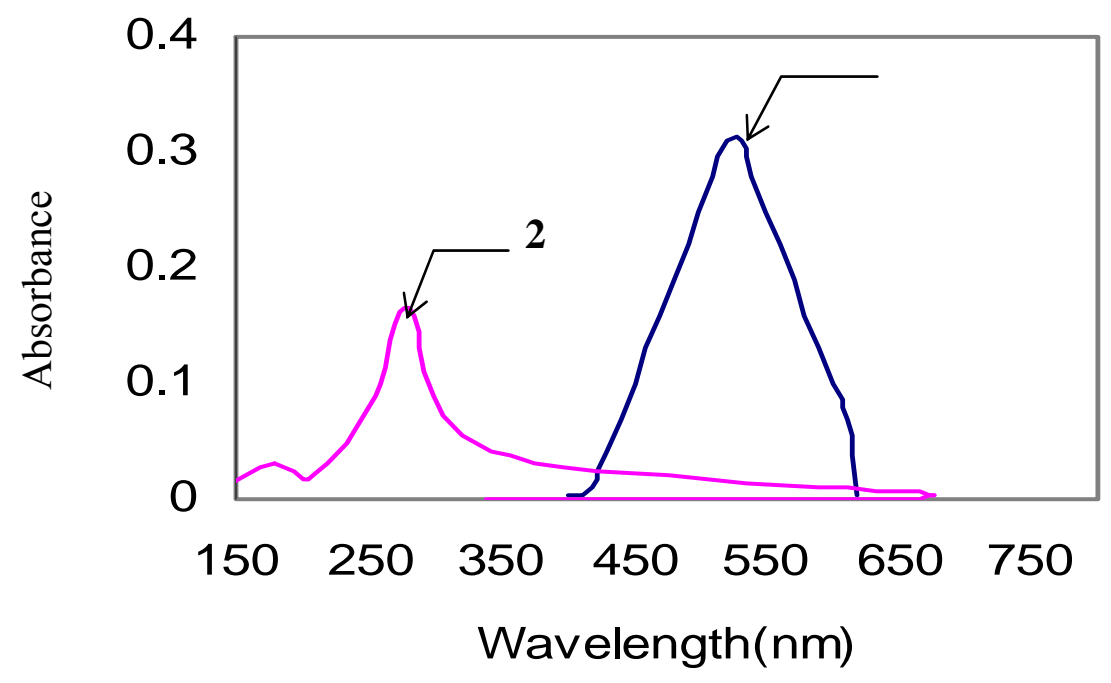

Fig. 1: Absorption spectra of $12 \mu \mathrm{g} \mathrm{ml}^{-1} 1$ - naphthylamine measured, (1)against blank, (2) blank against distilled water.

\section{Quantification}

A plot of absorbance versus determined concentration ,Figure(2) shows that Beer's law is being obeyed over the range of 1 to $60 \mu \mathrm{g} / \mathrm{ml}$ of the solution. Negative deviation from Beer's law occurred beyond the upper determination limit.

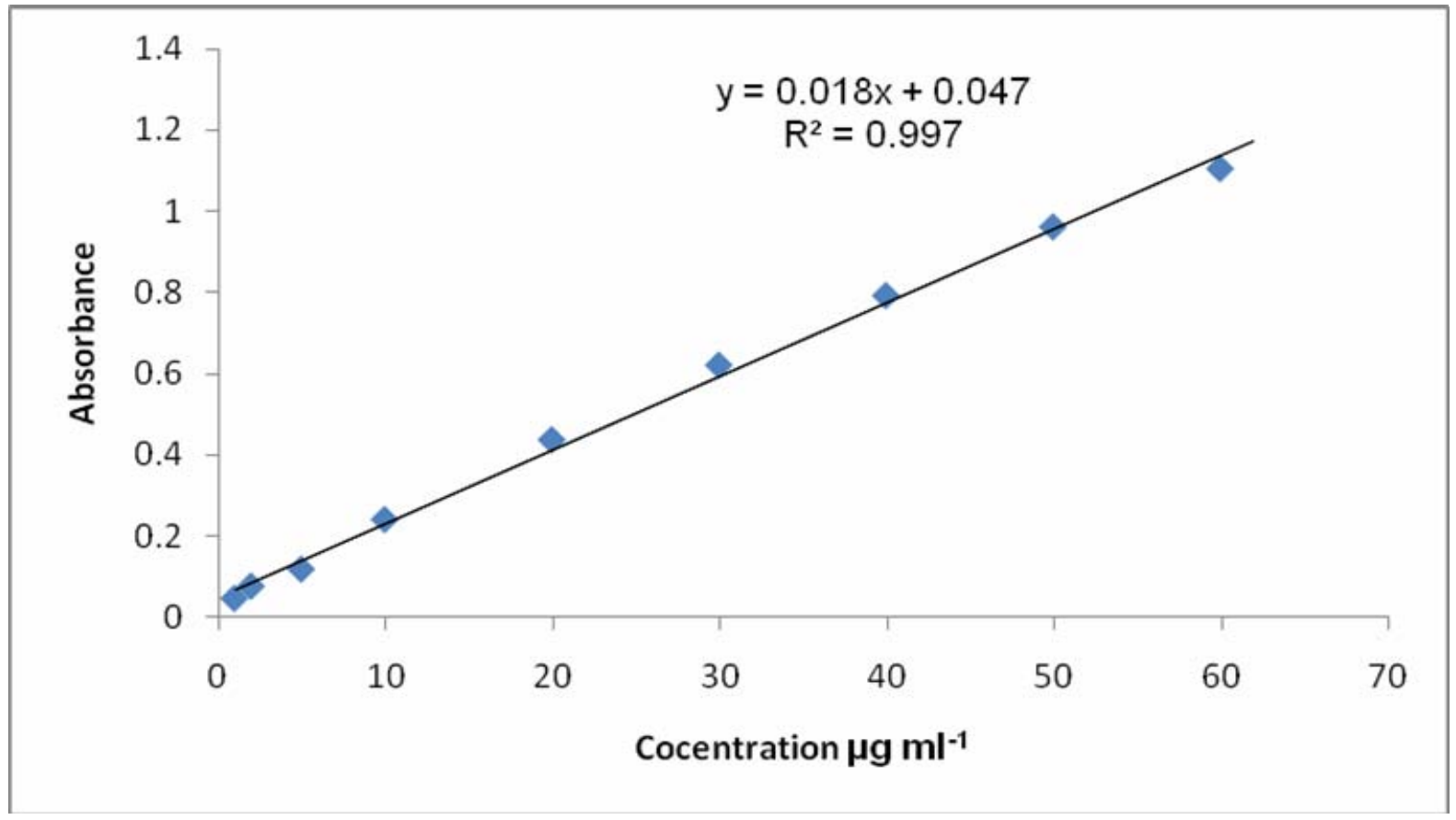

Fig. 2: Calibration graph for the determination of 1-naphthylamine.

\section{Accuracy and precision of the method}

To check the accuracy and precision of the method, 1-naphthylamine has been determined at three concentrations. The results are shown in Table (6) indicated that the method is performing well. 
Table 6: Accuracy and precision of the method

\begin{tabular}{|c|c|c|}
\hline $\begin{array}{c}\text { Amount of 1-naphthylamine } \\
\text { taken } \\
(\boldsymbol{\mu g} / \mathbf{m l})\end{array}$ & $\begin{array}{c}\text { Relative } \\
\text { error }^{*} \\
(\mathbf{\%})\end{array}$ & $\begin{array}{c}\text { Relative standard } \\
\text { deviation }^{*} \\
(\mathbf{\% )}\end{array}$ \\
\hline 5 & -1.20 & \pm 3.75 \\
\hline 20 & +0.14 & \pm 2.20 \\
\hline 40 & +0.06 & \pm 1.40 \\
\hline
\end{tabular}

* Average for five determinations.

\section{Nature of the product}

The method of continuous variations and of mole -ratio have shown that 1naphthylamine and pyrocatechol react in a 1:1 mole ratio.

\section{Application of the method}

Determination of 1-naphthylamine in river water

The present method has been applied to the determination of 1- naphthylamine in river water; the results of the determination are given in Table (7).

Table 7: Recovery of 1-naphthylamine in river water

\begin{tabular}{|c|c|c|c|}
\hline \multirow{2}{*}{$\begin{array}{c}\text { 1-Naphthylamine } \\
\text { added } \\
(\mu \mathrm{g} / \mathrm{ml})\end{array}$} & \multicolumn{3}{|c|}{$\begin{array}{c}\text { Recovery \% of 1- naphthylamine per } \\
\text { ml of river water used }\end{array}$} \\
\hline & 1 & 3 & 5 \\
\hline 5 & 98.4 & 99.1 & 101.6 \\
\hline 20 & 100.2 & 99.56 & 98 \\
\hline 50 & 99.6 & 98.3 & 102.5 \\
\hline
\end{tabular}

\section{Determination of 1-naphthylamine in sea water}

Sea water has been prepared (Henriksen,1965) and 1-naphthylamine has been assayed in sea water by the present method, and the results are shown in Table (8).

Table 8: Recovery of 1-naphthylamine in sea water

\begin{tabular}{|c|c|c|c|}
\hline \multirow{2}{*}{$\begin{array}{c}\text { 1-Naphthylamine } \\
\text { added } \\
(\mu \mathrm{g} / \mathrm{ml})\end{array}$} & \multicolumn{3}{|c|}{$\begin{array}{l}\text { Recovery \% of } 1 \text { - naphthylamine } \\
\text { per } \mathrm{ml} \text { of sea water used }\end{array}$} \\
\hline & 1 & 3 & 5 \\
\hline 5 & 97.2 & 103.5 & 106.3 \\
\hline 20 & 102.4 & 104.1 & 105.8 \\
\hline 50 & 101.25 & 102 & 102.6 \\
\hline
\end{tabular}




\section{CONCLUSION}

A new spectrophotometric method has been proposed for the determination of 1naphthylamine in aqueous solution. The method is based on coupling of 1-naphthylamine with pyrocatechol reagent in the presence of potassium chromate to form a coloured dye which exhibits maximum absorption at $530 \mathrm{~nm}$. The molar absorptivity is $36851 . \mathrm{mol}^{-1} \mathrm{~cm}^{-1}$. The proposed method is applied to the determination of 1-naphthylamine in river water and sea water.

\section{REFERENCES}

Al-Hemiry, N. A. F., 2004. Spectrophotometric, Electrochemical and Flow Injection Determination of some Toxics and Drugs-Application to Various Sample, Ph.D. Thesis, Mosul University, $33 \mathrm{p}$.

Henriksen, A., 1965. An Automatic Method for Determining Nitrate and Nitrite in Fresh and Saline Waters, Analyst, 90, pp.83- 88 .

Ismail, N. D., 1986. Spectrophotometric Analysis of Some Sulphonamides by Formation of Azo Dye, M.Sc. Thesis, Mosul University, 43 p.

Jarjees, I. A., 2006. Development of Spectrophotometric Methods for Determination of 1Naphthylamine Via Diazometry and Flow Injection Techniques- Application to River, M.Sc. Thesis, Mosul University.

Korenman, I. Ya., 1967. Absorptiometric Determination of 1-naphthylamine, Trans, Khim. Tekhnol, (Gor'kii), 1, 137; Anal. Abst.,1968 , 15, 540320 p.

Lenkhold, V., 1933. Colorimetric Determination of $\alpha$-naphthylamine in Technical naphthionate, Anilinokrasochnaya prom.,3, 87 p.; Chem. Abst., 1933, 27, 5277 p.

Lugg, B. A., 1963. Stabilized Diazonium Salts as Analytical Reagents for the Determination of Air-Borne Phenol and Amines, Anal. Chem., 35: 899 p.

Norwitz ,G. and Keliher, P. N., 1986. Continued Investigation of the Diazotization and Coupling Spectrophotometric Technique for the Determination of Aromatic Amines with 8-amino-1-hydroxy- naphthalene-3,6-disulphonic acid N-(1naphthyl) Ethylene Diamines as Coupling Agents, Talanta, 33, $311 \mathrm{p}$.

Snell, F. D. and Snell, T., 1962. Dictionary of Commercial Chemicals, 3rd, Edn., D. Van Nostrand Company, Inc., $361 \mathrm{p}$.

Sulaiman, B. and Bashir, W. A., 1984. Spectrophotometric Determination of 1Naphthylamine in Aqueous Solution by Coupling with Diazotised 4Aminoacetophenone, Analyst, 109, 1409 p.

Younis, T.I. , 1994. Photometric Assay of 1-Naphthylamine by Azo Coupling, M. Sc. Thesis, Mosul University. 